\title{
Pengaruh Penggunaan Mulsa Alang-Alang, Kenikir dan Kirinyu terhadap Pertumbuhan dan Hasil Bawang Merah Di Tanah Mediteran pada Musim Penghujan
}

DOI 10.18196/pt.2015.042.73-77

\author{
Mulyono \\ Program Studi Agroteknologi, Fakultas Pertanian, Universitas Muhammadiyah Yogyakarta, \\ Jl. Lingkar Selatan, Kasihan, Bantul, Yogyakarta 55183, Indonesia, Telp. 0274387656 , \\ e-mail:mulyonobdr@yahoo.com
}

\begin{abstract}
ABSTRAK
Penelitian ini dilaksanakan di tanah mediteran yang terletak di Desa Simo, Kecamatan Simo, Kabupaten Boyolali, Jawa Tengah. Penelitian ini dilaksanakan dengan percobaan lapangan menggunakan rancangan perlakuan faktor tunggal yang disusun dalam rancangan lingkungan acak kelompok lengkap (RAKL) masing masing perlakuan diulang tiga kali. Perlakuan yang dicobakan meliputi kontrol (PO), mulsa alang-alang (P1), dan mulsa kirinyu (P2), masing-masing perlakuan diulang tiga kali. Parameter yang diamati meliputi tinggi tanaman, jumlah daun, jumlah umbi, berat umbi, berat segar tanaman, berat kering tanaman, berat segar gulma, berat kering gulma dan hasil per hektar. Mulsa alang-alang, kirinyu dan kenikir tidak berpengaruh nyata terhadap tinggi tanaman, jumlah daun, jumlah umbi per rumpun dan hasil per hektar pada tanaman bawang merah. Mulsa alang-alang, kirinyu dan kenikir berpengaruh nyata terhadap berat segar tanaman, berat kering tanaman dan berat umbi per rumpun. Mulsa kenikir memberikan hasil tertinggi pada parameter berat segar tanaman, berat kering tanaman dan berat umbi perrumpun. Pertumbuhan gulma pada pertanaman bawang merah dipengaruhi secara nyata oleh perlakuan mulsa organik. Mulsa alang-alang berkemampuan paling tinggi dalam menekan pertumbuhan gulma.

Kata kunci: Mulsa organic, Bawang merah, Musim Hujan, Tanah Mediteran
\end{abstract}

\begin{abstract}
The study was held in Simo village, Boyolali, Central Java. The study used field experiments with a single factor that arranged in randomized completely block design. The treatments were control (PO), Alang-alang as mulch (P1), Kirinyu as mulch (P2), and Kenikir as mulch (P3), each treatment was repeated three times. The parameters were plant height, number of leaf, fresh weight of plant, dry weight of plant, number of tuber per hill, weight of tuber per hill, yield, fresh weight and dry weight of weeds. The results showed that mulch grass, kirinyu and kenikir was not significantly affect plant height, leaf number, number of tubers per hill and yield per hectare. Mulching grass, and kenikir kirinyu affected on plant fresh weight, dry weight and plant weight of tubers per hill. Mulching kenikir improved the plant fresh weight, dry weight of plants and weight of tubers per hill. Morover, Alang-alang, Kirinyu, and Kenikir as organic mulch significanly decreased the growth and abundant of weed and improved the growth of shallot plant. Alang-alang was the most highest decreasing the growth of weed.

Keywords: Organic mulch, Shallot, The rainy season, Soil mediterranean
\end{abstract}

\section{PENDAHULUAN}

Komoditas hortikultura yang terdiri dari tanaman buah-buahan, sayuran, tanaman hias dan tanaman obat merupakan tanaman yang sangat prospektif untuk dikembangkan mengingat potensi sumberdaya alam, sumberdaya manusia, ketersediaan teknologi serta potensi serapan pasar di dalam negeri dan pasar internasional terus meningkat. Salah satu komoditi hortikultura yang dikembangkan dan memiliki prospek yang bagus adalah bawang merah. Bawang merah tergolong komoditi yang mempunyai nilai jual tinggi di pasaran. Keadaan ini berpengaruh baik terhadap perolehan pendapatan. Apalagi didukung dengan cepatnya perputaran modal usaha bawang merah. Pada umur 60-70 hari tanaman sudah bisa dipanen. Pertumbuhan produksi rata-rata bawang merah selama periode 1989-2003 sebesar 3,9 \% per tahun, sedangkan konsumsi rata-rata bawang merah untuk tahun 2004 adalah 4,56 kg/kapita/tahun atau $0,38 \mathrm{~kg} /$ kapita/bulan (BPS, 2004).

Sebagian besar bawang merah diproduksi oleh 
petani kecil dengan luas lahan usaha $<0,5$ ha. Berbagai varietas bawang merah yang diusahakan petani diantaranya adalah kuning (Rimpeg, Berawa, Sidapurna dan Tablet), Bangkok, Warso, Bima Timor, Bima Sawo, Bima Brebes, Engkel, Bangkok, Philipines dan Thailand. Kebutuhan bawang merah di Indonesia belum dapat dipenuhi dari produksi dalam negeri maka terpaksa dilakukan impor walaupun pada saat tertentu pun dilakukan ekspor. Terjadinya ekspor dan impor pada tahun yang sama disebabkan antara lain musim panen bawang merah tidak merata sepanjang tahun.

Pengaruh iklim yang kurang baik dapat mempengaruhi penurunan produksi bawang merah. Mengingat permintaan konsumen dari waktu ke waktu terus meningkat, daerah sentra produksi dan pengusahaan bawang merah perlu ditingkatkan, sejalan dengan pertambahan jumlah penduduk dan daya beli masyarakat yang terus meningkat.

Peningkakan produksi bawang merah dapat ditempuh dengan jalan ekstensifikasi maupun intensifikasi. Ekstensifikasi dapat dilakukan pada lahan marginal seperti pada tanah regosol (pasir pantai) atau pada tanah Mediteran.

Tanah Mediteran adalah tanah yang terbentuk dari pelapukan batuan kapur dan bersifat tidak subur. Di Indonesia, tanah Mediteran dapat ditemukan pada tanah-tanah di Nusa Tenggara, Maluku, dan Jawa Tengah. Jenis tanah ini berasal dari batuan kapur keras (limestone), yang pada umumnya tersebar terdapat di daerah beriklim subhumid, topografi karst, dan lereng vulkan dengan ketinggian di bawah $400 \mathrm{~m}$. Tanah ini berwarna cokelat, merah, atau kuning. Sementara itu, warna merah kuning pada tanah mediteran berada di daerah topografi karst yang dikenal dengan sebutan Terra Rossa. Tanah mediteran yang berbahan induk batu kapur mempunyai nilai $\mathrm{pH}$ yang lebih tinggi dibanding dari yang berbahan induk batu pasir. $\mathrm{pH}$ tanah dapat dipengaruhi oleh beberapa faktor, yaitu bahan induk tanah, pengendapan, vegetasi alami, pertumbuhan tanaman, kedalaman tanah dan pupuk nitrogen.

Masalah utama dari jenis tanah mediteran adalah peka terhadap erosi, kandungan debu yang tinggi menyebabkan tanah cepat kering pada bagian permukaan sehingga dapat memutuskan akar terutama untuk tanaman yang berakar serabut seperti bawang merah. Tanah mediteran memiliki $\mathrm{pH}$ cukup tinggi yang seringkali di atas 7 . Tanah yang bersifat alkalis mengikat fosfat sehingga akan menjadi kendala bagi tanaman untuk tumbuh. Tanah Mediteran memiliki kendala fisik berupa kepekaannya terhadap erosi, suhu dan kelengasan, maka jika akan digunakan untuk budidaya bawang merah perlu diatasi kendala-kendala tersebut. Salah satu usaha yang dapat dilakukan dengan penggunaan mulsa. Mulsa adalah material penutup tanaman budidaya yang dimaksudkan untuk menjaga kelembaban tanah serta menekan pertumbuhan gulma dan penyakit sehingga membuat tanaman tersebut tumbuh dengan baik (Soepraptohardjo, 1976).

Mulsa Organik meliputi semua bahan sisa pertanian yang secara ekonomis kurang bermanfaat seperti jerami padi, batang jagung, batang kacang tanah, daun dan pelepah daun pisang, daun tebu, alang-alang, daun kirinyu dan serbuk gergaji. Dengan adanya bahan mulsa di atas permukaan tanah, energi air hujan akan ditahan oleh bahan mulsa tersebut sehingga agregat tanah tetap stabil dan terhindar dari proses penghancuran dan erosi. Penggunaan mulsa juga akan menjaga kondisi iklim mikro tanah seperti suhu dan kelembaban tanah sehingga tanah tidak cepat kering dan tidak mudah retak (Jajang, 
2009). Penelitian ini bertujuan untuk mengetahui pengaruh penggunaan mulsa organik yang berupa daun alang-alang daun kirinyu dan daun kenikir terhadap pertumbuhan dan hasil bawang merah di tanah mediteran.

\section{BAHAN DAN METODE}

Penelitian ini dilaksanakan di lahan sawah dengan jenis tanah mediteran yang terletak di Desa Simo, Kecamatan Simo, Kabupaten Boyolali, Jawa Tengah. Bahan yang digunakan dalam penelitian ini adalah bibit bawang merah, daun kirinyu, daun alang-alang, daun kenikir, pupuk NPK.

Penelitian ini dilaksanakan dengan percobaan lapangan menggunakan rancangan perlakuan faktor tunggal yang disusun dalam rancangan lingkungan acak kelompok lengkap (RAKL) masing masing perlakuan diulang tiga kali

Perlakuan yang dicobakan meliputi kontrol (P0), mulsa alang-alang (P1), mulsa kirinyu (P2) dan mulsa kenikir (P3) masing-masing perlakuan diulang tiga kali. Parameter yang digunakan meliputi: tinggi tanaman, jumlah daun, jumlah umbi, berat umbi per tanaman, hasil per hektar.

Parameter yang diamati meliputi tinggi tanaman, jumlah daun, jumlah umbi, berat umbi, berat segar tanaman, berat kering tanaman, berat segar gulma, berat kering gulma dan hasil per hektar. Data yang diperoleh dari masing-masing parameter diolah menggunakan sidik ragam (analysis of variance) dengan taraf kesalahan 5\%. Jika terdapat beda yang nyata antar perlakuan dilakukan uji lanjut dengan Duncan Multiple Range Test (DMRT) dengan taraf kesalahan 5\%.

\section{HASIL DAN PEMBAHASAN}

Pertumbuhan Tanaman

Mulsa dapat diartikan sebagai bahan atau material yang sengaja dihamparkan di permu- kaan tanah atau lahan pertanian (Andry, 2002). Mulsa dapat digolongkan dalam 2 kategori yaitu mulsa organik dan mulsa sintetik.

Mulsa organik meliputi semua bahan sisa pertanian yang secara ekonomis kurang bermanfaat seperti Alang-Alang, Kenikir maupun Kirinyu. Kenikir (Tagetes erectabe) dan Kirinyu (Chromolaena odorata) seringkali dianggap sebagai gulma karena kemampuannya untuk berkembang biak yang tinggi, namun mengandung nitrogen yang tinggi sehingga memiliki potensi untuk dimanfaatkan sebagai mulsa (Heyne, 1987).

Parameter pertumbuhan yang digunakan meliputi tinggi tanaman, jumlah daun, berat segar tanaman dan berat kering tanaman. Hasil rerata tinggi tanaman,jumlah daun, berat segar tanaman dan berat kering tanaman disajikan pada tabel 1 .

Tabel 1. Rerata Tinggi Tanaman (cm), Jumlah Daun, Berat Segar (gram), dan Berat Kering (gram)

\begin{tabular}{lcccc}
\hline $\begin{array}{l}\text { Perlakuan } \\
\text { mulsa }\end{array}$ & $\begin{array}{c}\text { Tinggi tanaman } \\
(\mathrm{cm})\end{array}$ & Jumlah daun & $\begin{array}{c}\text { Berat segar } \\
(\mathrm{gram})\end{array}$ & $\begin{array}{c}\text { Berat kering } \\
(\mathrm{gram})\end{array}$ \\
\hline Kontrol & $33,6 \mathrm{a}$ & $12,6 \mathrm{a}$ & $39,0 \mathrm{ab}$ & $23,0 \mathrm{ab}$ \\
Alang-alang & $32,8 \mathrm{a}$ & $8,4 \mathrm{a}$ & $31,4 \mathrm{~b}$ & $20,2 \mathrm{~b}$ \\
Kirinyu & $34,6 \mathrm{a}$ & $12,6 \mathrm{a}$ & $46,3 \mathrm{ab}$ & $28,8 \mathrm{ab}$ \\
Kenikir & $35,4 \mathrm{a}$ & $11,6 \mathrm{a}$ & $51,7 \mathrm{a}$ & $32,4 \mathrm{a}$ \\
\hline
\end{tabular}

Keterangan: Rerata yang diikuti huruf yang sama pada kolom menunjukkan tidak ada beda nyata berdasarkan DMRT pada taraf kesalahan $5 \%$.

Dari hasil sidik ragam parameter pertumbuhan tanaman, menunjukkan perlakuan berbagai macam mulsa organik tidak ada beda nyata pada parameter tinggi tanaman dan jumlah daun. Sementara pada parameter berat segar dan berat kering tanaman menunjukkan beda nyata. Penggunaan mulsa kenikir ternyata menghasilkan berat segar dan berat kering tanaman yang tertinggi yaitu berturut-turut 51,7 gram dan 32,4 gram. Sementara mulsa alang-alang menghasilkan berat segar dan berat kering tanaman yang terendah 
yaitu 31,4 gram dan 20,2 gram.

Kenikir merupakan jenis tanaman yang mempunyai nilai $\mathrm{C} / \mathrm{N}$ rendah sehingga jika digunakan sebagai mulsa akan cepat mengalami dekomposisi dan hasil dekomposisi yang banyak mengandung unsur $\mathrm{N}$ akan meningkatkan pertumbuhan tanaman. Di sisi lain mulsa alang-alang merupakan bahan yang nilai $\mathrm{C} / \mathrm{N}$ nya tinggi dan banyak kandungan sellulosenya sehingga selama pertumbuhan tanaman bawang merah belum terdekomposisi. Hal ini terlihat sewaktu tanaman bawang merah dipanen mulsa alang-alang masih kelihatan utuh.

\section{Hasil Tanaman}

Parameter hasil dan komponen hasil meliputi jumlah umbi per rumpun, berat umbi per rumpun dan hasil berupa berat umbi per hektar. Hasil rerata jumlah umbi per rumpun, berat umbi per rumpun dan hasil umbi per hektar disajikan pada tabel 2 .

Tabel 2. Rerata Jumlah Umbi Per Rumpun, Berat Umbi per Rumpun (gram), dan Hasil Umbi per Hektar (ton/ ha).

\begin{tabular}{lccc}
\hline Perlakuan mulsa & $\begin{array}{c}\text { Jumlah umbi Per } \\
\text { rumpun }\end{array}$ & $\begin{array}{c}\text { Berat umbi Per } \\
\text { rumpun (gram) }\end{array}$ & $\begin{array}{c}\text { Hasil umbi per } \\
\text { hektar (ton/ha) }\end{array}$ \\
\hline Kontrol & $5,9 \mathrm{a}$ & $21,5 \mathrm{ab}$ & $6,1 \mathrm{a}$ \\
Alang-alang & $5,0 \mathrm{a}$ & $19,0 \mathrm{~b}$ & $6,4 \mathrm{a}$ \\
Kirinyu & $6,3 \mathrm{a}$ & $26,4 \mathrm{ab}$ & $7,4 \mathrm{a}$ \\
Kenikir & $6,4 \mathrm{a}$ & $30,7 \mathrm{a}$ & $7,3 \mathrm{a}$ \\
\hline
\end{tabular}

Keterangan: Rerata yang diikuti huruf yang sama pada kolom menunjukkan tidak ada beda nyata berdasarkan DMRT pada taraf kesalahan $5 \%$.

Dari hasil sidik ragam parameter hasil dan komponen hasil tanaman, menunjukkan perlakuan berbagai macam mulsa organik tidak ada beda nyatan pada parameter jumlah umbi per rumpun dan hasil umbi per hektar. Jumlah umbi per rumpun secara statistik tidak dipengaruhi oleh penggunaan berbagai macam mulsa organik. Namun jika dilihat hasil reratanya mulsa kenikir cenderung menghasilkan jumlah umbi terbanyak yaitu 6,4 .

Penggunaan berbagai macam mulsa organik ternyata mempengaruhi berat umbi per rumpun. Mulsa kenikir tmenghasilkan berat umbi tertinggi (30,7 gram) disusul mulsa kirinyu (26,4 gram), sedangkan mulsa alang-alang tidak dapat meningkatkan jumlah umbi jika dibandingkan dengan kontrol (tanpa mulsa) bahkan cenderung memberikan berat umbi lebih rendah dibandingkan kontrol.

Kenikir merupakan bahan yang mudah mengalami dekomposisi sehingga akan meningkatkan kandungan unsur hara dalam tanah terutama N, P dan K serta unsur-unsur mikro. Unsur-unsur tersebut akan dimanfaatkan tanaman bawang merah sehingga menghasilkan berat umbi yang tertinggi. Daun alang-alang mengandung zat alellopaty sehingga penggunaan mulsa alang-alang justru menghambat pertumbuhan tanaman bawang merah (Rice, 1984).

\section{Pengamatan Gulma}

Untuk mengetahui pengaruh penggunaan mulsa organik terhadap pertumbuhan gulma pada pertanaman bawang merah maka dilakukan pengamatan berat segar gulma dan berat kering gulma pada petak percobaan. Tabel 3 menunjukkan rerata hasil pengamatan pertumbuhan gulma yang tumbuh dengan mengukur berat basah dan berat kering gulma.

Hasil sidik ragam berat segar gulma dan berat kering gulma, terdapat beda nyata antar perlakuan pada parameter berat segar gulma dan berat kering gulma. Hasil uji lanjutan dengan DMRT pada tingkat kesalahan $5 \%$ (tabel 3) menunjukkan bahwa penggunaan mulsa organik dapat menekan pertumbuhan gulma.

Berat segar gulma paling kecil pada perlakuan mulsa alang-alang (61,4 gram), kemudian bertu- 
rut-turut mulsa kirinyu (90,1 gram), dan mulsa kenikir (220,8 gram) sedangkan pada perlakuan tanpa mulsa (kontrol) menunjukkan berat segar gulma tertinggi (376,1 gram). Pada parameter berat kering gulma menunjukkan kecenderungan yang sama yaitu dari yang paling kecil mulsa alang-alang (14,2 gram), mulsa kirinyu (18,5 gram) dan mulsa kenikir (45,6 gram).

Tabel 3. Rerata Berat Segar Gulma dan Berat Kering Gulma pada Setiap Petak Percobaan

\begin{tabular}{lcc}
\hline Perlakuan & Berat segar gulma (gram) & Berat kering gulma (gram) \\
\hline Kontrol & $376,1 \mathrm{a}$ & $70,0 \mathrm{a}$ \\
Alang-alang & $61,8 \mathrm{c}$ & $14,2 \mathrm{C}$ \\
Kirinyu & $90,1 \mathrm{bc}$ & $18,5 \mathrm{C}$ \\
Kenikir & $220,8 \mathrm{~b}$ & $45,6 \mathrm{~b}$ \\
\hline
\end{tabular}

Keterangan: Rerata yang diikuti huruf yang sama pada kolom menunjukkan tidak ada beda nyata berdasarkan DMRT pada taraf kesalahan $5 \%$.

Alang-alang merupakan bahan yang mempunyai kandungan selulose yang tinggi sehingga lebih tahan terhadap proses dekomposisi. Selama pertumbuhan bawang merah mulsa alang-alang masih tetap utuh dan dapat menutupi permukaan tanah dalam jangka waktu yang cukup lama, sehingga pertumbuhan gulma dapat ditekan. Dari ketiga bahan mulsa organik kenikir merupakan bahan yang paling cepat mengalami dekomposisi sehingga periode penutupan permukaan tanah berjalan lebih singkat sehingga kurang efektif dalam menekan pertumbuhan gulma.

\section{SIMPULAN DAN SARAN}

Simpulan

Berdasarkan hasil analisis dan pembahasan dapat disimpulkan sebagai berikut:

1. Mulsa alang-alang, kirinyu dan kenikir tidak berpengaruh nyata terhadap tinggi tanaman, jumlah daun, jumlah umbi per rumpun dan hasil per hektar pada tanaman bawang merah.

2. Mulsa alang-alang, kirinyu dan kenikir ber- pengaruh nyata terhadap berat segar tanaman, berat kering tanaman dan berat umbi per rumpun. Mulsa kenikir memberikan hasil tertinggi pada parameter berat segar tanaman, berat kering tanaman dan berat umbi per rumpun.

3. Pertumbuan gulma pada pertanaman bawang merah dipengaruhi secara nyata oleh perlakuan mulsa organik. Mulsa alang-alang berkemampuan paling tinggi dalam menekan pertumuhan gulma

\section{Saran}

1. Penelitian ini dilakukan pada jenis tanah mediteran maka perlu dilakukan penelitian pada jenis tanah dan jenis tanaman yang lain.

2. Penelitian serupa perlu dilakukan pada musim kemarau mengingat penelitian ini dilakukan pada musim penghujan.

\section{DAFTAR PUSTAKA}

Andry Harits Umboh. 2002. Petunjuk Penggunaan Mulsa. Jakarta: Penebar Swadaya. 89 hal.

BPS (Badan Pusat Statistik). 2014. Produktivitas, Luas Panen dan Produksi Bawang Merah di Indonesia. www.bps.go.id. Diakses pada 17 April 2014

Jajang S.H. 2009. Pengaruh Jenis Mulsa Terhadap Pertumbuhan dan Hasil Tiga Kultivar Kentang (Solanum tuberosum L.) yang Ditanam di Dateran Medium. Jurnal Agronomi Indonesia 37(1):14-20

Heyne, K. 1987. Tumbuhan Berguna Indonesia (jilid 1). Yayasan Sarana Wana Jaya. Jakarta

Rice EL. 1984. Allelopathy. Second Edition. Orlando FL: Academic Press. USA

Soepraptohardjo. 1976. Jenis Tanah di Indonesia. Lembaga Penelitian Tanah. Bogor. 